\title{
Managing for the middle: rancher care ethics under uncertainty on Western Great Plains rangelands
}

\author{
Hailey Wilmer ${ }^{1} \mathbb{D} \cdot$ María E. Fernández-Giménez ${ }^{2} \cdot$ Shayan $_{\text {Ghajar }}{ }^{3} \cdot$ Peter Leigh Taylor $^{4} \cdot$ Caridad Souza $^{5}$. \\ Justin D. Derner ${ }^{6}$
}

Accepted: 26 November 2019

(C) This is a U.S. government work and not under copyright protection in the U.S.; foreign copyright protection may apply 2019

\begin{abstract}
Ranchers and pastoralists worldwide manage and depend upon resources from rangelands (which support indigenous vegetation with the potential for grazing) across Earth's terrestrial surface. In the Great Plains of North America rangeland ecology has increasingly recognized the importance of managing rangeland vegetation heterogeneity to address conservation and production goals. This paradigm, however, has limited application for ranchers as they manage extensive beef production operations under high levels of social-ecological complexity and uncertainty. We draw on the ethics of care theoretical framework to explore how ranchers choose management actions. We used modified grounded theory analysis of repeated interviews with ranchers to (1) compare rancher decision-making under relatively certain and uncertain conditions and (2) describe a typology of practices used to prioritize and choose management actions that maintain effective stewardship of these often multi-generational ranches. We contrast traditional decision-making frameworks with those described by interviewees when high levels of environmental and market uncertainty or ecological complexity led ranchers toward use of care-based, flexible and relational frameworks for decision-making. Ranchers facing complexity and uncertainty often sought "middle-ground" strategies to balance multiple, conflicting responsibilities in rangeland social-ecological systems. For example, ranchers' care-based decision-making leads to conservative stocking approaches to "manage for the middle," e.g. to limit risk under uncertain weather and forage availability conditions. Efforts to promote heterogeneity-based rangeland management for biodiversity conservation through the restoration of patch burn grazing and prairie dog conservation will require increased valuation of ranchers' care work.
\end{abstract}

Keywords Grasslands · Agriculture · Decision-making $\cdot$ Heterogeneity $\cdot$ Beef cow-calf $\cdot$ Production and conservation tradeoffs $\cdot$ Complexity

Hailey Wilmer

hailey.wilmer@usda.gov

María E. Fernández-Giménez

maria.fernandez-gimenez@colostate.edu

Shayan Ghajar

sghajar@vt.edu

Peter Leigh Taylor

pete.taylor@colostate.edu

Caridad Souza

caridad.souza@colostate.edu

Justin D. Derner

justin.derner@usda.gov

1 USDA-Agriculture Research Service, Rangeland Resources and Systems Research Unit, Fort Collins, CO 80526, USA
2 Department of Forest \& Rangeland Stewardship, Colorado State University, Fort Collins, CO 80523-1472, USA

3 Department of Crop and Soil Environmental Sciences, Virginia Polytechnic Institution and State University, Middleburg, VA 20117, USA

4 Department of Sociology, Colorado State University, Fort Collins, CO 80523, USA

5 Department of Ethnic Studies and Women's Studies and Gender Research, Colorado State University, Fort Collins, CO 80523, USA

6 USDA-Agriculture Research Service, Rangeland Resources and Systems Research Unit, Cheyenne, WY 82009, USA 


\section{Abbreviations}

AUE Animal unit equivalent

NRCS United States Department of Agriculture-Natural Resources Conservation Service

\section{Introduction}

This paper examines the ethical aspects of rancher decision-making under uncertainty to better understand the lived experience of ranchers in highly variable, complex social-ecological rangeland contexts. Rangelands, where the indigenous vegetation is managed with (or with the potential for) grazing, are a dominant landcover type extending across over $40 \%$ of the Earth's terrestrial surface where they support ranchers, pastoralists and rural communities (Gibson 2009). In the Great Plains of North America rangeland ecology has documented the importance of management for rangeland vegetation heterogeneity to address conservation and production goals. This paradigm, however, has limited application for working ranchers as they manage extensive beef production operations under high levels of social-ecological complexity and uncertainty. In order to support the sustainable management these ecosystems, adaptive capacity scholars seek to understand manager decision-making processes, including the ethical frameworks, used to navigate uncertainty. This study aims to answer the question: how does decision making operate from an ethical perspective on beef cattle ranches dealing with dynamic, uncertain and complex social-ecological conditions? We use Western Great Plains rancher decision-making as a case study to explain how managers pursue a good, moral life while making important decisions in the context of imperfect, incomplete, or uncertain information (Tronto 1994).

We first review the social-ecological context of rancher decision making and previous research in this area, which has largely described the distribution of conservation or stewardship-related decisions across ranching populations but not the processes of how moral decision-making operates in ranching families and communities (Sayre 2004). We argue that a consideration of rancher's care ethics, or how ranchers employ relational, care-based moral analysis particularly for decisions in complex and uncertain socialecological contexts, provides needed nuance to understanding rangeland conservation and ranch livelihood outcomes (Gilligan 1982). Using data from repeated interviews with ranchers in the Western Great Plains, we compare rancher decision making under relatively certain and uncertain conditions and then describe how care ethics shape rancher decision-making under complex and uncertain conditions. We discuss the implications of these findings for emergent ecological theory in the US Great Plains to illuminate the ethical complexities of translating this theory into practical application on the region's ranches. This research is important because it documents the nuanced decision-making processes of ranchers, who manage and care for extensive tracts of intact rangeland ecosystems and the associated processes of food production, biodiversity conservation and ranching livelihoods. To help inform management of these working lands, this study fills a gap in understanding between rangeland ecology and the human dimensions of rangelands which has hindered the application of conservation measures.

\section{Ranching social-ecological context in the Western Great Plains}

Ranchers' ability to navigate dynamic and complex ecological, weather and climate, and market conditions has implications for rural community viability, and for the extent and diversity of rangeland ecosystems (Brunson and Huntsinger 2008; Knight 2007). Ranchers have a number of grazing and ranch system options available to help address this variability, including stocking rate and grazing system selection. Stocking rates are relatively inflexible in North American ranch operations (Wilmer et al. 2018), but have a well-documented influence on rangeland vegetation species composition and production (Derner et al. 2008), wildlife habitat (Augustine et al. 2010, 2012), and other ecological processes that directly affect ranch economic returns, financial viability and biodiversity (Dunn et al. 2010; Irisarri et al. 2019). Grazing strategy selection reflects rancher cultures and family goals, as well as livestock handling traditions and infrastructure development across extensive landscapes (Bracy Knight et al. 2011; Roche et al. 2015; Wilmer and Fernández-Giménez 2015), labor inputs, and drought mitigation needs for beef production (Derner and Augustine 2016) though the ecological benefits of some grazing strategies may not extend to all rangeland systems (Briske et al. 2011; Roche et al. 2015). Both stocking rate and grazing strategy decisions can affect vegetation heterogeneity (and thus biodiversity) of rangelands at broader spatial and longer temporal scales (Briske et al. 2003; Fuhlendorf et al. 2006; Hovick et al. 2014). Ranchers' intra- and inter-annual tactical decisions feed into less frequent strategic and operational decisions that influence land tenure and land use, thus interacting with ranch-, community-, and regional-level social and food systems throughout the rural Western US.

In semi-arid and arid ranching systems such as those in the Western US and Australia, uncertainty created by variability in precipitation and extreme weather events, market and livestock health dynamics can produce anxiety and limit proactive planning (Marshall 2010; Marshall and Smajg1 2013). Climate science and seasonal forecasts are often unable to inform key decisions (such as stocking rate) at spatial and temporal scales relevant to ranchers (Kachergis et al. 2014). The context-specific 
nature of topography, soils, climate, social and historical dimensions means technical recommendations often fail to inform ranches across broad geographic areas. Natural resource management scholarship has turned toward identifying and supporting the capacity of managers to adapt to these dynamics without giving management prescriptions (Fernández-Giménez et al. 2015; Galvin et al. 2016; Marshall 2016). Ranchers' perceptions of risk and management uncertainty, and their planning, learning and strategic skills, flexibility and interest in change are important aspects of their capacity to adapt to dynamic climatic and economic conditions (Marshall and Smajgl 2013; Marshall and Stokes 2014).

\section{Rancher decision-making research}

Scholarship from across disciplines has contributed to a large body of ranch management research. Agricultural economics has contributed greatly to our understanding of managing risk in complex ranching operations under uncertain conditions, including increasingly variable climate on rangelands (Ruff et al. 2016; Ritten et al. 2010; Torell 2010; Hamilton et al. 2016). There is also a large body of work exploring the distribution of innovation (or conservation practice) adoption behavior and risk perceptions across ranching populations (Bennett 1969; Brunson and Burritt 2009; Didier and Brunson 2004; Roche 2016; Lubell et al. 2013; Sun et al. 2014; Sorice et al. 2012). Evaluations of conservation decision-making in ranching, like in farming, provide insight into personal and ranch characteristics that are likely to lead to innovation adoption and conservation, including education level, operation size, capital, income, access to information and social networks (Lubell et al. 2013). Few independent variables consistently provide explanatory power for conservation decisions across studies of agriculture practice adoption (Prokopy et al. 2019). Rangeland social scientists have recognized the need to engage with a wider range of theoretical approaches for understanding how ranching decisions are made (Sayre 2004).

Recent work has documented the ethical aspects of ranching (Ellis 2013) as well as the role of ranchers' situated, local and cultural knowledge in shaping material ecological outcomes and food systems (Knapp and Fernández-Giménez 2008; Brunson and Huntsinger 2008; Bentley Brymer et al. 2018). Ranching traditions reflect historical processes and multi-generation adaptations to local conditions (Bennett 1969; Cunfer and Krausmann 2015), and a well-documented motivation for conservation and lifestyle amenities (Torell et al. 2001; Sorice et al. 2012; York et al. 2019). These ranching and cowboy (labor) experiences are often communicated through oral traditions, poetry and folk art surrounding rangelands (Specht 2019; e.g. Lund 2014, track 12).

\section{Ranch complexity and uncertainty as ethical issues}

Traditional management practices, if inflexible and prescriptive, may not provide guidance when conditions become surprising, dynamic, or very complex (Holling and Meffe 1996). Adaptive management scholars, even those working in controlled experimental settings with simplified system dynamics, now recognize that natural resource management involves making judgments even when the picture of management-outcome feedbacks is incomplete or ambiguous (Hruska et al. 2017; Fernández-Giménez et al. 2018). Managers often do not have the luxury of waiting to learn more about the system or potential outcomes before they must act (Coppock 2011). While ranch management decisions intuitively involve consideration of economic costs and benefits, the complex social and ecological consequences of range management mean there is also an ethical component to these choices.

If we recognize the interrelatedness of ranch families and workers, livestock, and rangeland ecosystems (Ellis 2013; Lien et al. 2017), we can see the need to understand ranchers' efforts not just to make sound economic decisions, but to live lives that are in their terms good and moral. At the same time, adaptive management scholarship has in the past focused more on processes of collaborative learning and science-based management than on ethical processes. Thus, ranchers' ethical decision-making is a growing area of scholarship (Lien et al. 2017), with implications for both theoretical and practical aspects of ecosystem management. In this paper, we explore how concepts of care help enrich our understanding of rancher decision-making under uncertainty by illuminating the ethical, emotional and embodied nature of rangeland management decision-making shaping social and ecological structures and processes across range landscapes. These ethics-informed decisions include goal setting, responses to drought, grazing strategy selection, and stocking rate decisions.

\section{Theoretical framework}

The ethics of care framework provides an opportunity to move beyond documentation of what managers know or what they decide to do to an investigation of how they navigate complex human-nature relationships and uncertainty (Plumwood 1991). It does this by allowing us to ask how decision-making operates on ranches by tracing the moral experiences of managers as they evaluate and select actions in specific contexts, such as managing forage and cattle during drought. We use the concept of care as described by Carrol Gilligan's development psychology research on women's decision making in crisis (Gilligan 1982) and foundational work by Noddings (1984), 
illustrated conceptually in relation to rangeland systems in Fig. 1. We used this framework in our empirical analysis of our repeated interviews to identify decision-making conditions, or examples of decision making under more or less complexity and uncertainty, various phases of decision making, and the specific suites of actions taken by ranchers under these conditions and phases. This framework thus organizes the ethical aspects of ranch decisionmaking processes in a way that accounts for both rule and care-based approaches to ranch management, recognizing that ranchers' decisions involve analyses not only of optimizing production or economic returns, but also of how to live good, moral lives in social-ecological systems.

Care ethics involve the practice of a moral life linked to caring and caretaking of self and others (Gilligan 1982; Whyte and Cuomo 2016). Care ethics emphasize the role in morality of connections over rules, and relationships over individual moral judgment and principles (Gilligan 1982; Flanagan and Jackson 1987), and contrast sharply with conventional ethical theories that elevate moral reason/ thinking (Noddings 1984). Care is about responsiveness, relationships and reciprocity (Lawson 2007, 2009) and is based in the practice of coping with our dependence on one another (Tronto 1994, 1999) and our environments, animals and other non-human beings (Curtin 1991; Haraway 2003). Focused at the social rather than individual level, care ethics emphasizes establishment and maintenance of relations between care-givers and receivers. Care-based decisions are contextual, and grounded in a responsibility for care, not on rules that dictate a decision or action (referred to as justice-based ethics, see Tronto 1994). As such, they allow for flexibility and specificity, and cannot be practiced in the abstract (Lawson 2009). Noddings (1984) distinguishes care-giving (acts of care which can be performed under any ethical framework) from care-ethics, a moral way of life and decision-making which requires higher moral analysis.
Our theoretical approach distinguishes between decisionmaking processes ranchers employ during relatively certain and uncertain and/or complex contexts (Fig. 1). Because this analysis is focused on decision-making processes, rather than just outcomes, it is possible that actual actions or outcomes of those processes might be similar. Put another way, we are not examining if ranchers decide to implement a conservation practice, but how they decide, given various levels of certainty and complexity. Care ethics is informative for uncertain and complex contexts because these are often morally challenging or crises experiences for ranchers. Gilligan's (1982) study of women's moral development during and after crisis illustrated how women grappled with multiple, conflicting responsibilities such as ideologies of selflessness and the need for autonomy and self-care. This analysis is informative for evaluations of decision-making in other contexts, such as ranching drought or economic stress. In order to identify specific aspects of care ethics in ranching, our framework specifically incorporates Tronto's (1994) four phases of care ethics: (1) caring about (recognizing a need for care); (2) caring for (or assuming responsibility to care); (3) caregiving (material tasks of care); and (4) care receiving (response of the cared-for to such care).

Caring assumes that decision-makers rely on their subjective experience and emotion in choosing a course of action. Growing interest in knowledge as social has re-framed knowledge from an ideal of nomothetic and objective information to a situated, embodied practice (Oeberst et al. 2016; Haraway 1988) and recognized the role of human experience and empathy in decision-making (Hill Collins 2002; Haraway 1988; Harding 2006). Jaggar (2015) argues that the false dichotomy between "rationality" and "emotion" serves to separate us from our own senses and perceptions, and from the knowledge that our emotions can help create. Feeling and thinking are both important processes for care (Gilligan 1982). Tensions between justice and care

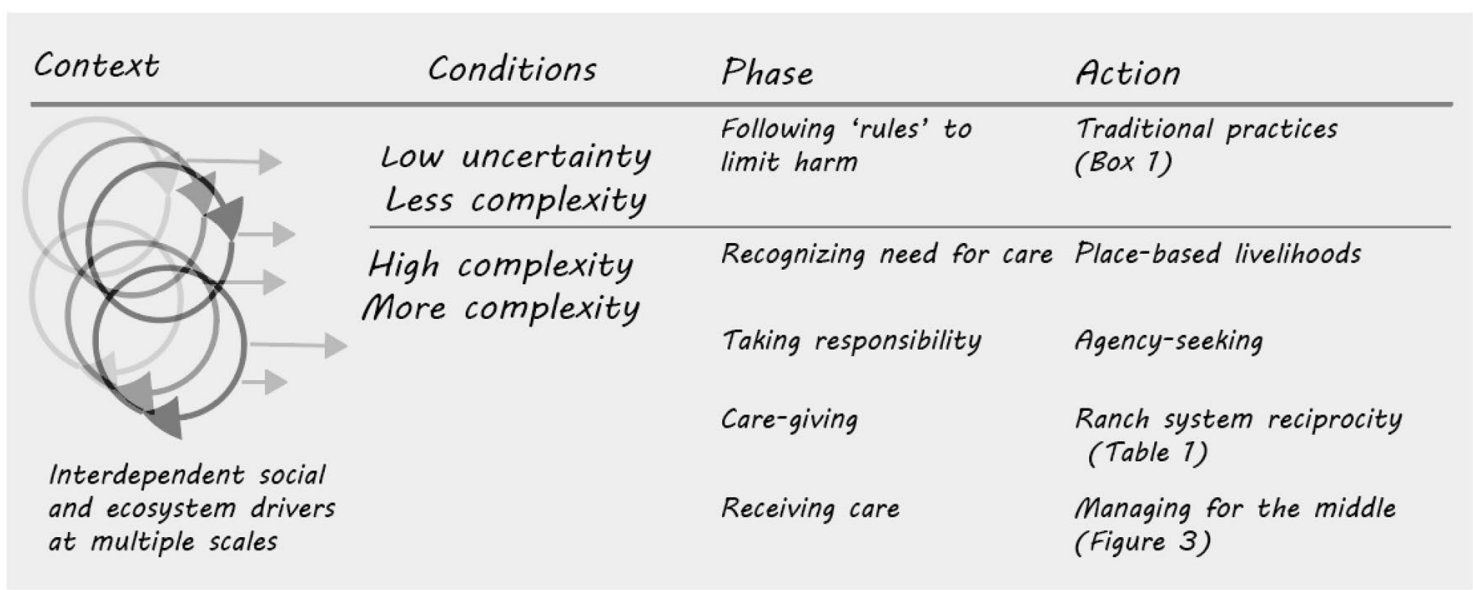

Fig. 1 Framework to understand ethical basis for ranch decision-making under variable levels of uncertainty and complexity 
as binary gendered, competing frameworks have been addressed through work by Held (1995) who argues that justice-(rule-) based decision making can be nested within care ethics. Empirical research suggests decision-makers employ both justice (rule-based) and care-based ethics to their choices, as different moral approaches are needed for different domains (Flanagan and Jackson 1987; Ford and Lowery 1986; Held 1995).

Disasters, crises, and other adverse/extreme events can activate care-based decision-making and behavior at the community scale (Rizza and Pereira 2014). For example, Aldrich and Meyer (2015) demonstrate the importance of interpersonal relationships and social capital for community resilience in the face of external threats. Care-based behavior in a community facing a crisis can, to some extent, mitigate shortcomings in the responses of governments or other formal organizations by providing decentralized networks less likely to overlook vulnerable populations such as the elderly or poor (Dominelli 2013).

Theoretically, rangeland management care ethics could advance mainstream environmental ethics, where a lack of moral consideration of non-humans and ecosystems is linked to environmental destruction, but care work is rarely taken seriously, even as well-established scholars (including Naess and Leopold) have called for increased care of ecosystems (Whyte and Cuomo 2016). The theoretical domain of care in environmental decision-making is foremost in indigenous philosophy (Johnson and Murton 2007; Battiste and Youngblood Henderson 2000). Here concepts of care, reciprocity, responsibility and stewardship are integral in the communications and actions of indigenous environmentalists, researchers and educators (Black Elk 2016; Deloria 1988; Tall Bear 2017; Tuhiwai Smith 2013). Ecofeminists have also engaged with care ethics to examine the interdependence of moral relationships between multiple species, particularly humans and livestock (Curtin 1991; Warren 1987). This work has discussed the mutual benefits and limits of care work, including the gendered and oppressive effects of unequal care relationships (Flanagan and Jackson 1987; Held 1995; Tronto 1994). Care work has received growing attention in empirical investigations of on-farm decisionmaking (Roesch-McNally et al. 2018; Turner et al. 2014; Shisler and Sbicca 2019). For example, Shisler and Sbicca (2019) describe how women farmers in Colorado expand what it means to be a farmer by practicing care work. Roesch-McNally et al's (2018) interviews with corn farmers in the US Midwest found that the development of farmers' soil conservation ethic served as a "social-ecological feedback" that helped farmers resolve the tradeoff between short-term production goals and long-term conservation goals. York et al. (2019) surveyed public lands ranchers and found that these ranchers believed they were managing for multifunctional (conservation and production) outcomes, and that they managed private and public land in the same way to the same standard.

\section{Methods}

\section{Study site}

Our study was focused on the working rangelands of the Western Great Plains of the US. The ranches we studied were largely family-owned/operated ranching operations that rely on forage from biologically diverse native short- and mixed-grass prairies, restored rangeland, and mixed irrigated cropping systems, held in a patchwork of public and private ownership. Native rangelands in this system are grazing and drought resistant (Milchunas and Lauenroth 1993; Milchunas et al. 1988) having evolved under heavy grazing pressure from native herbivores, including bison and prairie dogs, and with periodic exposure to fire and drought (Augustine et al. 2012; Augustine and Derner 2012; Augustine et al. 2008; Ruppert et al. 2015; Milchunas and Lauenroth 1993; Milchunas et al. 1988). Species composition change stemming from even heavy, continuous, season-long grazing is slow and directional (Porensky et al. 2017). On extensively managed rangelands in this region, cattle production outcomes are affected by extreme weather events, such as drought, and by variability in the amount, timing and intensity of precipitation within and among years (Derner et al. 2008; Dunn et al. 2010; Reeves et al. 2013). Beef production outcomes per acre are understood to have trade-offs with per head daily animal gains, and range science has long advised that optimal stocking rates are those moderate enough not to waste forage or require purchase of emergency feed (Bement 1969).

Rangelands are also resilient to politics and policy, perhaps more so than previously recognized (Sayre et al. 2017). Ranchers consider the influence of socio-cultural and economic relations on their rangeland resources, communities, and largely family-farm- businesses (Didier and Brunson 2004; Fulton et al. 2011). These influences include wildlife management and public lands regulations (Charnley et al. 2014; Huntsinger et al. 1997); global trade and changing social demands for meat production (Easdale and Domptail 2014); market integration (MacDonald and McBride 2009), energy extraction development (Lai and Kreuter 2012), shifting land uses toward amenity ranching, non-production uses, and urbanization (Gosnell and Abrams 2011; Sorice et al. 2014); and ecological and social consequences of climate change (Joyce et al. 2013). Ranch family succession and ranchers' life-histories also affect management, rancher roles, and land use change (Wilmer and Fernández-Giménez 2015, 2016). 


\section{Case selection}

This research, carried out between 2012 and 2016, included 17 cow-calf or cow-calf plus yearling operations that rely on forage from rangelands (northern mixed-prairie in eastern Wyoming or shortgrass steppe in eastern Colorado) for at least part of the year (see Fig. 2). Ranchers were invited to participate through a network sampling method that took advantage of existing research contacts (Noy 2008). Participants self-identified as "ranchers" and relied on income from selling calves, yearlings, or from custom grazing (renting pasture to other ranchers), though they received some income from farming, energy development, hunting, or offranch sources including employment. The ranches (including privately-owned land, and public grazing permits and private leases) ranged in size from 300 to 22,000 ha with 40-1000 animal unit equivalents (AUE) on an annual basis. All but one operation included public land grazing permits, though dependence on public lands varied among ranches and years. Family ranch tenure ranged from multigenerational (including 100-year-old "centennial" ranches) to firstgeneration, including families that identified as settlers and homesteaders, to those that purchased a ranch after retiring from a first career.

\section{Data collection and analysis}

This is a longitudinal study, in which a total of 30 ranchers on 17 total ranches were interviewed, with at least one person on each ranch interviewed repeatedly between the summers of 2012 (all 8 Wyoming ranchers and 2 Colorado ranches) and 2014-2016 (all 8 Wyoming and 9 Colorado ranches). These years included the 2012 regional flashdrought, or rapid onset drought (Otkin et al. 2016), followed by a period of relative wetness for the region, and with relatively variable beef prices, including with strong calf prices in 2015 (USDA-NASS 2019).

Interview data were collected under Colorado State University human subjects IRB protocol $12-3381 \mathrm{H}$. The interviewees were 17 men and 13 women, included rancher primary or co-decision makers and their families. Interviews involved one to five people, ages mid-20s to mid80 s, two generations in four cases (including three couples and their children, a father/daughter team and a mother/ son team), couples in five cases, and individual primary decision makers in seven cases (five men and two women). All interviewees were white. During the first interview, we asked ranchers to describe their ranching operations, grazing management, responses to drought, management priorities, and definitions of success. In subsequent interviews we asked ranchers to describe changes in management and the context and outcomes of those changes since their last interview. To better understand ranchers' ethical frameworks in relation to these decisions, we asked them to describe in more detail how they thought through and experienced changes on their ranches and difficult decisions, such as those around coping with drought. We also asked managers to describe their relationship with nature to a non-rancher audience. Additional supporting data included management plans, news articles, email correspondence, and field notes from participant observation, which occurred throughout the study by the first author (Glesne 1992). Interviews were audio recorded and transcribed, and analysis was documented with an audit trail and memos throughout the study (Lincoln and Guba 1986; Morse et al. 2008).

To interpret ranch decision-making processes in relation to the care ethics framework, we engaged in an iterative examination of the care literature, rangeland ecology literature and our qualitative data. This process involved multiple rounds of coding and triangulation with relevant literature (Charmaz 2006; Glaser and Strauss 2017). Repeated interviews allowed us to identify patterns in these key events, and to clarify examples of rancher decision-making at a cultural level, on a daily, seasonal and annual basis, and during acute disturbance events (drought, wildfire, etc.). While collecting data we began initial coding in the R library RQDA (Huang 2016) and in a digital spreadsheet, labeling chunks of data for information that described ranchers' decision-making processes (Charmaz 2006). Ranchers' reasoning for their actions and traditional adaptations became more explicit through repeated interviews. Rancher participants aided in data collection and interpretation. Once all interviews were completed, we coded for analytic themes related to major changes in management, perceptions of success, decisions made during and after drought, as well as the social, economic, and cultural context of the ranch operation. We compared code patterns across the ranches over time using a table and synthesized these into a conceptual model, describing traditional and care-based decision-making, which we also compared to the original interviews and to current literature in order to search for contradictory examples (Charmaz 2006). As part of this comparison, we responded to an unanticipated tendency by the ranchers to describe what they would not consider doing during their interviews, which yielded new insights into the cultural parameters of their decision-making particularly during more certain conditions. We used poetic analysis to summarize and interpret these negative statements, arranging them thematically for a thick display of data given the contradictions and similarities across rancher interviewees (Fernández-Giménez et al. 2018). We conducted member-checking by discussing and refining initial results with rancher participants and with two non-participating ranchers. 




Fig. 2 Study area including family-operated ranches in Wyoming and Colorado, USA. This area includes the semi-arid shortgrass steppe (Colorado) and mixed-prairie (Wyoming) ecosystems 


\section{Findings}

Below we describe rancher decision-making under both relatively certain and uncertain/complex contexts. In relatively foreseeable contexts, decision-making processes rely on rules or traditions that indicate a response. In more complex or uncertain conditions, decision-making processes are more relational and care-based. We recognize system drivers included climate, weather, economic, socio-cultural, animal health, vegetation, and wildlife dynamics, which affected ranchers' experiences as individuals, within families, and across community, regional, and global scales (Holling and Gunderson 2002).

In practice, these two experiences are often related and may even result in the same action. Ranchers' traditional management practices used under certain or less complex conditions shape their cultural practices and the nature of their interdependence with highly variable ecosystems. This interdependence prompts them to take responsibility for rangeland ecosystems and rural communities. The responsibility is manifest in the practice of specific management strategies ranchers described to give care. In selecting management actions, ranchers prioritize their livelihoods and human well-being, but also consider the benefit to non-humans, including select wildlife species, plant communities, and livestock. Ranchers' actions and relationships are tied to ecosystems and places, which shape how they seek compromise solutions that they perceive best serve social and ecological goals. We label this approach "managing for the middle", as it is characterized by compromise and middle-ground efforts that reduce risk in rangeland systems. We describe the framework in more detail below, specifically noting how ranchers assume responsibility for, give, and receive responses for care in ranching systems, while at times engaging with more rulebased, rather than care-based frameworks.

\section{Ranching in relatively foreseeable conditions}

When social and biophysical conditions are relatively similar to previous experiences, rancher decision-making is based upon long-standing traditions and culture, lessons from their past experiences and the importance of historical decisions (path-dependence) to their overall operational structure relative to climate and emergent social dynamics (Bennett 1969). For example, the sequence and seasonality of major ranch decisions may vary little from year to year for decades (see Box 1). These decisions included class and number of livestock, cattle management and sequence of pasture use, investment in hay or other winter forage resources, and involvement in the local community. As one rancher remarked,

Let's start in the winter. We ah, December we start feeding protein pellets, cake. Which I spoke about. Then, in ah January we start feeding hay, in February we start calving. And then you're getting into spring by then. So you're calving in the spring and feeding. So your daily ah management plans are how many cows are in each pasture, how much feed you've gotta put out each day, and in those groups how the cattle are looking. You know you've got to today you know we may have to, what we do is when the calves are about a week old, we vaccinate them, de-horn 'em, and band the bull calves, and then we move that group to a different pasture. Ah, so we'll do that pretty much weekly. So you know that's ok today's the day we're going to do that process, you know, so I guess that would be daily planning. And then you know you get into April and you're planning on branding and getting with the neighbors so you can help them and they can help you. And so that would be kind of a daily ritual. You know getting on the phone kind of visiting with everybody, kinda getting things planned and of course feeding every day. And then you get into summer your daily things change where you're a little more lenient. You don't have pressure quite as much, you know you get the cows turned out on summer grass, it kind of relaxes things at home, you can you know run off and have some fun.

In the interviews, traditional ranch practices were often described as heuristics or rules to limit harm to humans and ecosystems. Notably, we often identified this type of decision-making within interviews when ranchers described actions they would not consider taking, thereby staking out the parameters of their cultural and operational boundaries or marking the "rules" of the place. Examples of these "negative statements" were summarized and thematically organized for display in Box 1 . This display illustrates that rule-based decisions vary across ranches, but generally emphasize conservative stocking rates to limit overgrazing ("we don't overgraze ever" or "take too much from the land"), and demonstrate ranchers' need for proactive planning, learning, and some level of stability and predictability (e.g. "we are not going to not have a plan"). Cultural memory of place and weather variability also influence choice of specific livestock breeding (through "well-adapted cows") and stocking decisions (e.g. "we're not feeding all them cows through this drought"), adjustments to avoid toxic plants (often Delphinium spp.), and choice of livestock handling techniques: the use horses and dogs, roping, all-terrain vehicles, and chutes or tables when working livestock, (e.g. "we are not a 
Box 1 Poetic analysis of negative statements of rancher traditions
We are not going under from debt Or selling out to the big ranch next door.

We are not going to fight the environment or have the most complicated system possible. We have limited time and resources.

We are not going to spend all our money buying time putting up winter feeding hay.

We don't overgraze, We don't overgraze ever.

We don't hammer it like they did in the 50s, take too much from the land, overstay our welcome, or run more than 300 pair.

But I am not wedded to the idea of 300 pair, I realized I do not need cows to make me happy.

We don't

buy cattle,

live flamboyantly, mind paying taxes,

like taking government assistance.

We are not going to sell off our cows.

We do not

sell all our well-adapted cows in drought. But we're not keeping all our cows, Because we're not feeding all of them cows through this drought.

We are not going

to not

have a plan,

or abandon that plan.

Ranching is not zig-zagging around reinventing the wheel.

All the time.
We are not going to sell off our cows.

We do not

sell all our well-adapted cows in drought.

But we're not keeping all our cows, Because we're not feeding all of them cows through this drought.

We are not going

to not

have a plan, or abandon that plan.

Ranching is not zig-zagging around reinventing the wheel.

All the time.

We do not depend on tradition.

We are not a cowboy operation.

Did you see the one horse decorating the lawn On your way in?

We do not go with the herd, we quit the herd.

Hell,

we quit the herd quitters.

But don't get too trigger happy, we don't need a revolution now, do we?

We are not going to change

much,

too much

too fast

for the sake of change.

We're not young anymore, but

We don't stagnate.

We don't stop,

sit around,

sit still,

don't get greedy

and never stop

learning.

And we don't have years like this very often. cowboy operation"). Ranchers often emphasized a "tradition of breaking with tradition", (e.g. "we quit the herd"). Ranchers across the interviews emphasized that they "do not depend on tradition" while at the same time resisting abrupt change ("don't get too trigger happy"). This speaks to the cultural importance of both independence and innovativeness in a ranching community and to the relatively "innovative" subset of the broader ranching population we interviewed.

\section{Ranching under complexity and uncertainty}

When conditions reach higher levels of complexity, uncertainty, risk and/or urgency, rancher decision-making becomes more relational. It is more iterative and dependent on an understanding of relationships among many variables including both human and non-humans. These uncertain conditions include variability in forage availability within and among years, in the cattle market, or under changing 
family or livestock health conditions, extreme weather events, or combinations of events. Management of complex wildlife and rangeland vegetation communities are also included in this category. Care-based decision-making also emerged in the interviews relative to concerns and responses to the 2012 flash drought. Situations such as an extreme drought can create emotionally demanding and high-risk decision-making contexts, with cattle's lives and ranchers' livelihoods at stake. In these situations, ranchers may be less likely to have reliable information or local knowledge of management-ecosystem feedbacks (Marshall 2010), and so approach decision-making with consideration of their relationships to landscapes, and livestock, vegetation, and wildlife communities. We describe these in terms of stages of care: recognizing the need for care, assuming responsibility for care, and acts of care or reciprocity, following Tronto (1994).

\section{Recognizing the need for care}

The first phase of care-based ranching decision-making is the recognition of the need for care. In complex or uncertain contexts, ranchers refer to their knowledge and connection to place. Interview data reveal that ranchers have an overt interest in sustaining rangeland ecosystems and speak freely about their interdependence with complex ecosystems. As one Wyoming woman in her early 70s said, "That's been a huge thing in the family, just through the multi- generations, just the fact that we really try to take care of our land because that's what keeps us in business." Care-based decision-making depends on this connection to place, which includes but is not singularly motivated by, an interest in ecosystem relationships and function. They described successful rangeland management and ranching operations as those that sustain viable economic and ecological systems for future generations of ranchers. For example, one Wyoming man in his 60s said in 2014:

I ask myself, do I want to spend time and money on a tree that I will never see? It won't save a calf in a storm in my lifetime. I have been planting trees up there in this meadow for 20 years and there are a few to show for it. I thought I could stick cows in here in the storm and they would be protected, but it is not coming true very fast. There's something to good stewardship that just says, 'you save it for future generations.

Thus, their interest in conservation is rooted in their emotional connections to ranching livelihoods. Another Wyoming man in his mid-60s said: "My goals are still to leave the ranch in better shape than I found it. I don't want to go to the touchy-feely, tree hugger part of it, [but I'm trying to] make the ranch more environmentally sound, and just make it easier really. I mean it's about money in the long run."
Ranching livelihoods shape, and are shaped by, specific places. These places encompass a broad range of social and ecological relationships, often across the memory of several ranching generations. Wildlife and vegetation diversity are part of the places that maintain a ranching family's relationships and livelihoods, and so range landscapes include not just what ranchers see on the landscape but who they are and "how they (ranchers) look" to their neighbors, and to consumers and the public (Wylie 2017). As one Colorado rancher noted, acknowledging both the difficulties of his labor-intensive and often financially unstable livelihood: "I don't always like what I do, but I like where I live." The linkage between the identity of a ranching family and the land (deeded or otherwise), often experienced via intermediate relationships with livestock, is complex, dynamic, and specific to each ranch, but also nested in place-based ranching community networks, and in the broader ranching industry (Herman 2015).

Recognizing the need for care was described across all ranches in the study, specifically around concerns for rangeland species composition and production as these variables relate to long-term profitability. For example, a Wyoming rancher (male, mid-60s) describes his conceptualization of sustainability:

To me sustainability is you've got things balanced in your life and in your environment so that you can continue the ranch for the next generation; it's not about Agenda 21. Sustainability is just being able to continue, and so hopefully 50 or 75 years from now, if I was able to come back and look at the ranch, it would still be a nice place that somebody might want to live and make money.

Place shaped ranching family and community networks. For example, this Colorado couple in their mid and late 50s reflected on three decades of ranching together, noting the links between their appreciation for the place they live and their relationship:

Woman: "You know the business. It takes everything you have. It just does. I'm glad we hung onto [the ranch]. Just being there and going through the, like riding through the pasture or walking, it's just so nice. Have you been out there on the hills? It's just, ahh, this is ours. You can't really own the land, but it's ours as much as it can be anybody's. It's just such a great feeling. It really is."

Man: "I think that's why I wanted to stay a lot. When I was a kid I remember being a kid in school and the teacher would just be [calling my name]. I'd be sitting there day-dreaming about getting home. I'd just gotten a pony. Riding my pony out to get the milk cows through the hills. You know, in the springtime and 
stuff. I guess maybe that's part of why I wanted to stay there. Was just that."

Woman: "I think we both love it and appreciate it in the same way. I think that's a strong bond we have. We love the wildlife. We love the wildflowers. We just have that, you know, we have the same appreciation for the place."

\section{Assuming responsibility for care}

Ranchers we interviewed recognized close links between social and ecological thresholds in times of uncertainty or complexity. They described how their success was constrained by the complexities of weather, livestock behavior and biology, and rangeland biodiversity and productivity. Ranchers are vulnerable to and dependent upon complex and uncontrollable natural systems. This vulnerability often creates a feeling of lack of control, or as one man in Colorado (40s) described "It's kind of roll the dice and see what happens", and drove ranchers to seek a sense of agency in their decision-making, as Colorado women in her 40's stated: "Our goal is to make money and be efficient, and to learn how to utilize the tools that are around you, somebody has done to help you advance faster, something that somebody's learned." Ranchers had agency when they have the ability to make decisions that serve operational goals, despite the variability and uncertainty of markets, weather and other dynamics on the ranch.

For example, grazing management is one area of ranch decision-making where ranchers described having a strong sense of agency. Ranchers said their grazing management decisions enabled them to work within the constraints and opportunities of their specific ranch landscapes to promote desired rangeland species composition, provide higher quality forage, and limit time and labor required to gather or handle livestock. While the constraints of market and livestock genetic resources made stocking-rate decisions much less flexible, grazing rotation planning enabled ranchers to anticipate and respond to system variability. Ranchers said they observed positive results in terms of their objectives in relatively short time spans, including changes in changes in beef production and forage availability. One Wyoming rancher, in his mid-60s, described their ranch's grazing management as a rare opportunity to find agency in a complex, uncontrollable system:

Well, you live with what you've got. Financially, and nature-wise too. You kind of make plans, we always try to keep our stocking arranged where we can get by on them, the average dry year, without having to adjust things, but we usually try and make sure we're not overstocked for a dry year, but when you get the droughts like we had in 2012 and the ones 10 years ago, you do have to change things but you have to adapt to what you've got, and still try to make sure you keep the resource from being permanently damaged.

Proactive planning, an interest in learning, and an emphasis on adaptation can build ranchers' sense of agency, but severe weather events can undermine that sense and limit proactive approaches, particularly in relation to ranchers' responsibility to reduce animal suffering and prevent death. An example of this was ranchers' description of calf loss during spring storms, at which times ranchers put in long hours to attend to livestock wellbeing, as described by a Wyoming (male) rancher in his 60s:

We had three significant storms during calving season this year. When that [storm] happens you're out there with them. You can't be out there at night, all night. We're out there all day long with them. Out there as soon as we can see anything in the morning. We're with them until it's absolutely too dark to see anything.

Another man in 40s described how he and his wife coped with a "wreck" - an extreme storm leading to calf mortality in their first year owning their own ranch: "During that wreck it was one of those things of you do everything you possibly can, and then when all the chips fall you gather them all up and figure out what to do with what you've got." One Colorado woman in her 60s described the most difficult part of ranch decision-making as:

"...the stress that comes with wanting to make the right decision. Wondering if you did make the right decision. When you don't make the right decision, the consequences. For me the consequence is: if I make the wrong decision with a cow or something or if I overgraze a pasture it's like life. I damaged life."

\section{Acts of care: rangeland reciprocity}

When making decisions in complex and uncertain contexts, such as during drought or when developing new grazing management approaches, ranchers acted to promote reciprocity, or mutual benefit for people, wildlife and vegetation on their ranches (Table 1). Ranchers' narratives repeatedly described the importance of practices of reciprocity that they believed were attentive to their relationships with livestock, wildlife, and vegetation communities. For example, one Wyoming man in his mid-60s noted:

After you've spent your whole life on a piece of land, you respect it. As you start making more money you feel like you can put a little more back, or fix that problem that the drought did so many years ago, or a mistake that your ancestors made. 


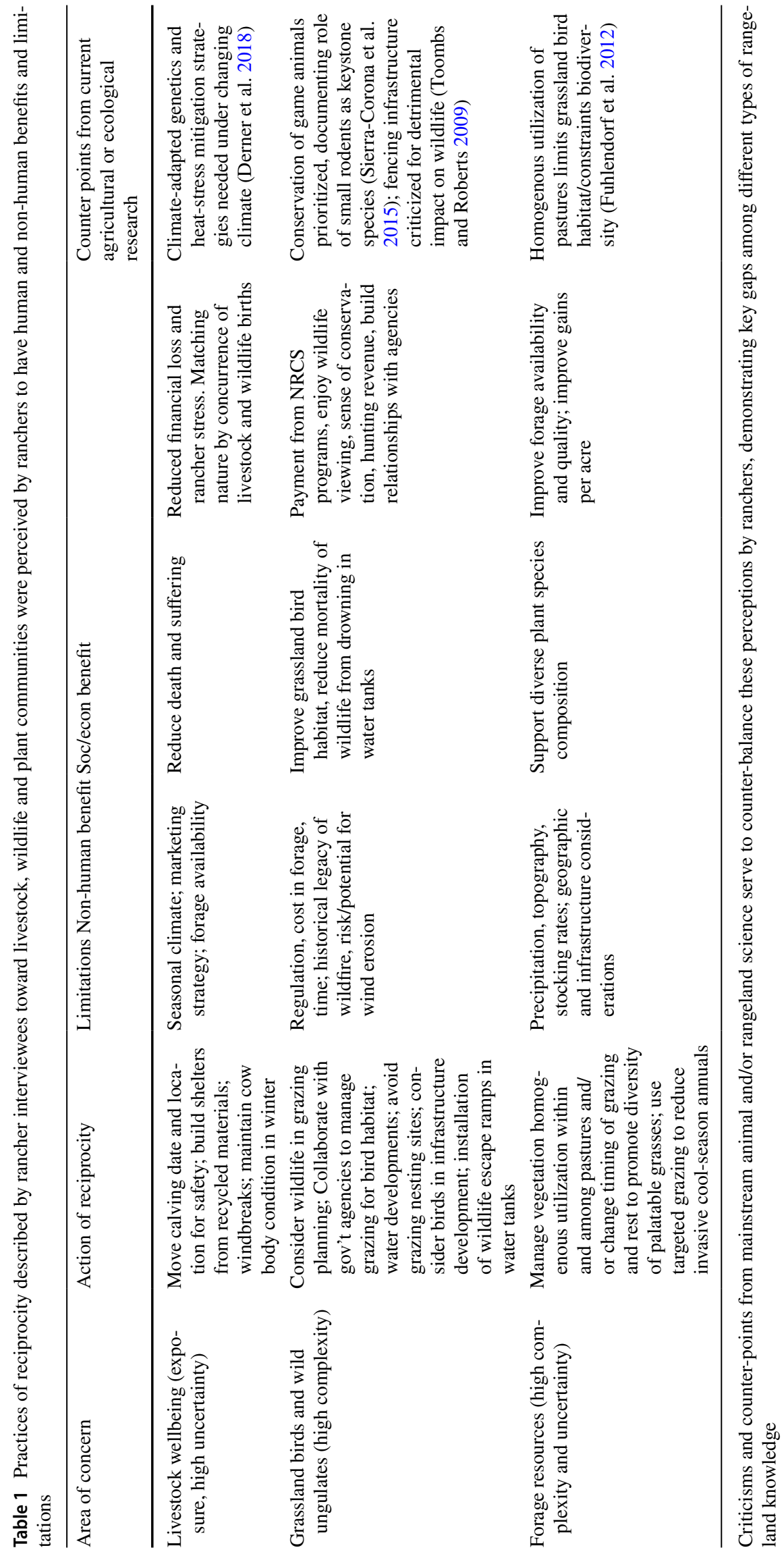


Across the interviews, ranchers said their livelihood strategies had the potential to contribute to long-term degradation of rangeland resources if they were not careful to prevent over-harvest. They referred to instances of past heavy grazing as "mistakes", and said they tried to limit where and how often they "pushed" the rangeland ecosystem for beef production objectives. One woman (in her early 40s) said succinctly: "The philosophy is to not push it on an average [precipitation] year." Across the interviews, ranchers said they had little agency when managing system variability, particularly in their flexibility to respond to timing and amount of precipitation. This vulnerability left ranchers in a struggle to balance short-term profit-("taking") and long-term ecological and economic outcomes-("leaving") during high risk or novel decision-making situations. During difficult decisions, ranchers found ways to compromise, or "manage for the middle" via the heuristic to "take half, leave half", or as one Colorado woman in her 50s said, "moderation in all things." A lack of forage in the flash drought of 2012 called for a decision to either cull a herd or buy hay, but rather than decide on one or the other, a Wyoming rancher (a man in his mid-60s) described trying to do a little of each:

You can't just say 'Oh yeah we're going to leave 50 percent of the grass.' There are a lot of years we've got to use 70 or 80 percent. Or you go buy some extra land or ship your cows to Kansas. You've got to find a way to [maintain] financial [viability], and you know sometimes, just like buying two hundred ton of hay or keeping the cows? That's one of those tough ones where you lay awake at nights going $[\ldots]$ and sometimes there's no good answer, and sometimes it's halfway in-between. Which is kind of what I'm planning, not buy as much hay, but we're going to have to buy some. Cull the cow herd down but we've got to have enough cows to pay the mortgage payment a year from now.

Ranchers found middle-ground solutions to reduce vulnerability of livestock, vegetation communities and livelihoods to variable weather and uncertain conditions (Table 1). This "managing for the middle" approach involved specific management practices: conservative, relatively similar across years stocking rates, and efforts to graze cattle more uniformly across the landscape. This approach was also characterized by (prevalent-see Roche et al. 2015) moderately stocked, long-duration rotational grazing systems. By managing for the middle, ranchers strove to maintain or reinforce interdependent relationships within ranching systems by reducing exposure to variability.

To summarize, the capacity of ranchers to make decisions under conditions of climate, social and financial uncertainty is bolstered by responsive, care-based ethical frameworks rooted in concern for relationships and informed by emotional knowledge of place and place-based livelihoods. Given the context of ranch management, care is really a matter of survival for people dependent upon highly variable systems and who care for livestock in extensive grazing contexts. Care improves ranchers' ability to act within unexpected and complex social and ecological dynamics because it allows ranchers to respond to change and take responsibility for their livelihoods and environment.

\section{Discussion}

\section{Response of the cared for: the implications of managing for the middle}

Our case study provides a qualitative description of ranchers' care-based decision-making and helps build a nuanced theoretical approach to understanding of adaptive management and ranching social-ecological relations. Ranchers' ethical decision-making processes shape range landscapes and influence their role in biodiversity conservation and food systems. Existing literature has assessed the effectiveness and limitations of various rangeland and animal management practices to critically examine ranchers' reasoning for their actions (Table 1). Rancher efforts to improve livestock well-being may be bolstered under a changing climate by use of climate-adapted breeds and heat-stress mitigation strategies in confined feeding scenarios (Derner et al. 2018). Additionally, ranchers' efforts to conserve wildlife populations as reported in the interviews prioritize big game species and also largely exclude the use of prescribed fire, an essential ecological process in this fire-adapted ecosystem (Augustine et al. 2010). Increased fencing infrastructure, often implemented under conservation planning efforts, has been criticized for negative impacts on numerous wildlife species (Toombs and Roberts 2009; Bracy Knight et al. 2011). Finally, grazing strategies that promote homogenous vegetation utilization to improve diversity within plant communities may optimize beef production at the expense of broader ecosystem biodiversity (Fuhlendorf et al. 2006).

Qualitative case studies are well suited to build new middle-range theory to inform future hypothesis testing when existing theories lack explanatory power for current research questions (Ragin 2014). The sampling logic of this study is intended to provide depth in quality of the description of phenomena, rather than breadth in generalizability about the distribution of behavior or phenomena, but it provides important insights into ranchers' ethical frameworks that could be tested in the future with a larger-N questionnaire. Future research might also consider additional ecological sampling to better link rancher ethical frameworks to rangeland management outcomes. The interview data illustrate how conservative, consistent stocking rates across years, 
and homogeneity-creating grazing strategies can result from ranchers' responses to uncertainty as forage availability and weather impacts change quickly. As noted, this reasoning often precludes grazing, vegetation, and wildlife management practices that promote heterogeneous vegetation structure (Fig. 3). Under the managing for the middle logic, resting pastures is wasting possible forage, while the use of prescribed burns to improve forage quality or influence species composition, heavy grazing (especially in drought) or tolerance of prairie dog populations leads to destruction of ecosystem and resource base (Sayre 2017). This was particularly prominent in Colorado ranchers' interviews, where there is a perception that ungrazed grass will break off and blow away during winter. Additionally, this reasoning is supported by a classic paradigm of rangeland science (Bement 1969) (see Fig. 3) and promoted widely through state and federal outreach programs and through small-mammal extermination programs (Fuhlendorf et al. 2012; Twidwell et al. 2013; Joshi et al. 2017; Sayre and Fernández-Giménez 2003; Sayre 2017).

Rangeland scientists and conservation biologists have described the correlation between heterogeneous vegetation structure and composition of habitat and biodiversity (Tews et al. 2004; Knopf and Samson 1997; Davis et al. 2019) and to the importance of prairie dogs as keystone species (Sierra-Corona et al. 2015) and fire and heavy grazing as key ecological processes in the Western Great Plains (Skagen et al. 2018; Derner et al. 2009). In contrast to Bement's model (1969) of optimum stocking, the heterogeneity-based paradigm of rangeland ecology (Fig. 3, Fuhlendorf and Engle 2001) recognizes vegetation structure heterogeneity shaped in evolutionary history in the semi-arid Western Great Plains by variable precipitation, heavy grazing pressure from small mammals, fire, and grazing interactions and frequent, often prolonged drought. Various case studies in the region have also demonstrated the benefits of managing for heterogeneous structure across larger, community or regional landscapes with benefits from stored forage in drought (White and Conley 2007). The optimal stocking paradigm, which assumes that ungrazed grass is wasted and heavy stocking will require supplementation of expensive emergency feed, limits the spectrum of vegetation structure available, and may also limit ranch drought resilience because it precludes grass storage ("grassbanking") (Fig. 3). Grazing experiments have demonstrated that patch burn grazing, and grazing on prairie dog colonies, can have limited negative impact on cattle weight gains in the experimental setting (Derner et al. 2006), but ranchers often argue that these management practices have negative financial consequences at the ranch scale (one grazing experiments rarely reach, see Sayre 2017). This complexity explains why ranchers may resist the heterogeneity management

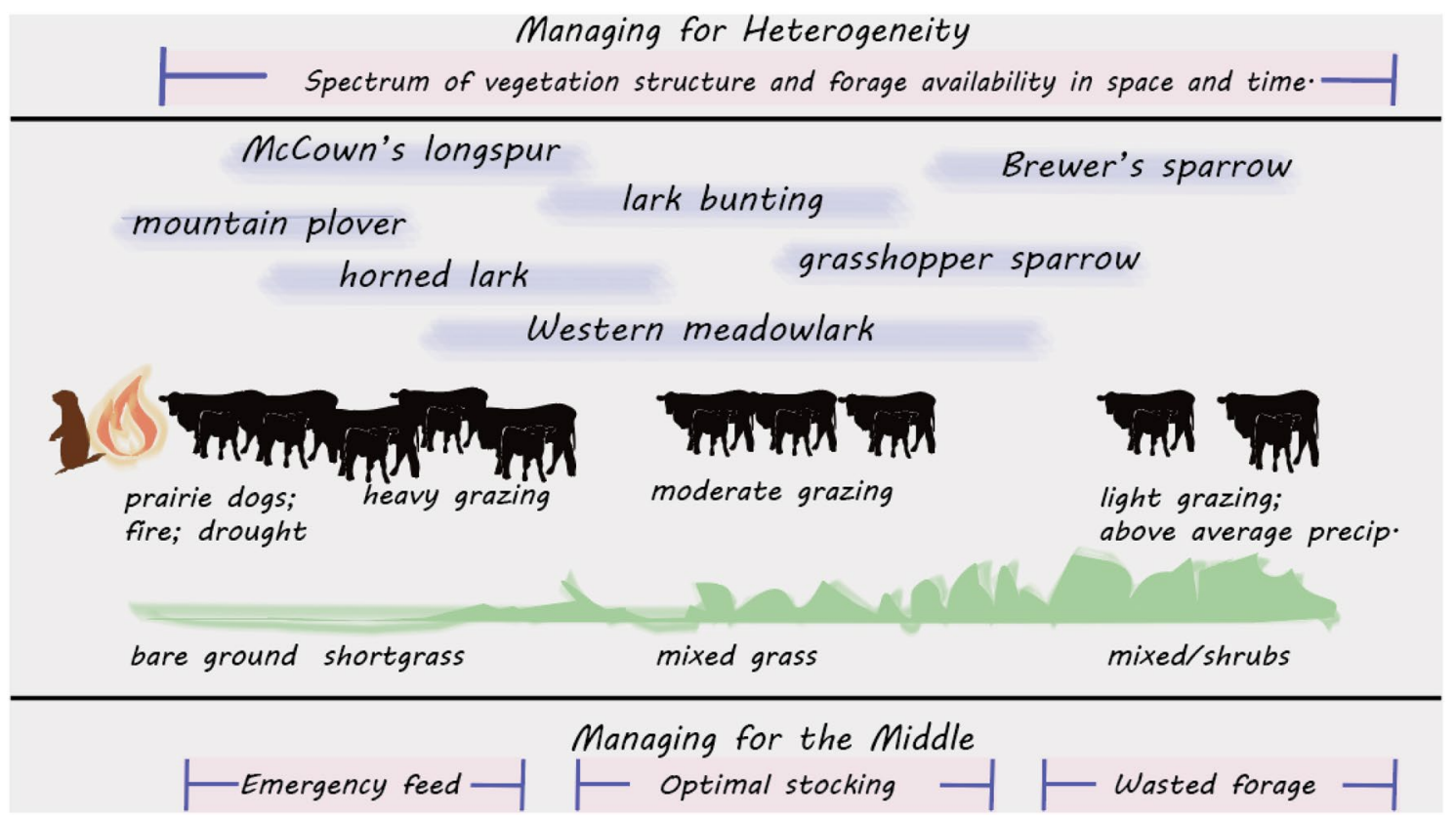

Fig. 3 Conceptual diagram of heterogeneity-based paradigm of rangeland management adapted from Knopf and Sampson (1997) and Davis et al. (2019). For maximum biodiversity conservation (Fuhlendorf and Engle 2001) and drought resilience (Derner and Augustine 2016; Agrawal 2008), large ungulate grazing would interact with climate, fire and small mammal grazing to create a large spectrum of rangeland structure, thus supporting a suite of grassland bird species. Our study describes how managers select a "managing for the middle" approach via care-based decision-making, and illustrates the ethical aspects of stocking rate decisions which enhance Bement's (1969) production-oriented stocking rate recommendations for "optimal stocking." 
paradigm, celebrated by conservation biologists, for both economic and ecological reasons that are interpreted through their ethical frameworks.

\section{Working with ranchers: beyond the land ethic}

There are clear parallels between the practices of reciprocity and the ethic of care we describe and Leopold's "The Land Ethic," which concludes his collection of environmental essays in A Sand County Almanac (Leopold 1949). During repeated interviews and participant observation, ranchers described their biodiversity management objectives, and sometimes quoted Leopold. Of particular interest to them was Leopold's discussion of the concept of community in the Land Ethic essay. The Land Ethic "changes the role of Homo sapiens from conqueror of the land-community to plain member and citizen of it. It implies respect for his fellow members and respect for the community as a whole." (Leopold 1949, p. 203). The Land Ethic resonates with ranchers because it links to their recognition of their responsibility to manage range landscapes for multiple species- including humans, wildlife, livestock, and vegetation. Ranchers' interest in conserving ecosystem goods and services was discussed by Turner et al. (2014), whom also considered the conflict between land ethics of different (farming and ranching) agriculture decision-makers and implications for land use in the Great Plains. A closer look at the Land Ethic through the lens of the findings of this study reveals a subtle misalignment between ranchers' management ethics and Leopold's concept. While the Land Ethic pushes managers to consider their position as somewhere beyond "conqueror of the land-community," the privileging of rancher livelihoods in their decision-making maintains the rancher's identity as steward of the land community, not "plain member and citizen of it."

This means that ranchers' ethical frameworks cannot be described simply in terms of Leopold's Land Ethic or even by the framings of American environmentalism (Whyte and Cuomo 2016). The extent to which ranchers value and prioritize care work as an essential component of their land management ethic is notable, though our interviews suggest that rancher efforts to limit, repair or prevent harm and/ or promote well-being of their families, livestock, wildlife and other actors in ranch ecosystems are not part of equal relationships with non-humans. Reciprocity and care of ranchers is better framed within the context of their interdependence with rangeland ecosystems, and to biophysical and market constraints within those variable systems, rather than an egalitarian view of human-nature relationships. That is, care-based ethical frameworks promote care at the ranch scale, while often precluding decisions (heavy grazing, prescribed fire or management for prairie dog populations) that enhance ecological outcomes at broader spatial scales via the creation of vegetation heterogeneity. Additionally, ranching's hierarchical interpretation of human-nature relationships is reinforced through the ways that ranching shapes, and is shaped by, the ongoing American colonial project and ideas of dominion and stewardship (Ellis 2013). Ranchers we interviewed discussed sincere and continual efforts to take care of ranching systems and described making many care-based decisions that were context-responsive, focused on relationships, and emotionally responsible to their desire to live a good, moral life in ranching. However, the historical and economic context of ranching is such that ranchers' perceptions of which relationships to care for and how to best do that caring may be misaligned with both current range and animal science recommendations and mainstream Western environmental ethics.

Ranchers' care work must also be recognized within the context of place attachment. Interviews suggest place attachment is part of the long-term relationships that guide rancher decisions in uncertain, complex situations on particular scales (grazing management at the ranch-scale), but not on others (regional Great Plains ecosystems). Previous research suggests place attachment may have a negative relationship with perceptions of risk and interest in change at multiple scales (operational trajectory changes, decisions to leave ranching) (Marshall and Smajgl 2013; Marshall and Stokes 2014). Our results provide some nuance to previous findings regarding rancher place attachment, as attachment reflects interest in livelihood sustainability and knowledge of ecological relationships. In an increasingly globalized and homogenous world, linkages between places have deepened as the distinction between local and global has eroded (Holloway 2002; Wylie 2017). Ranchers' goals to maintain a connection to place and for the use of ranching landscapes is likely to play an increasingly important role in both their rangeland management practices and their land-use and succession planning. How this attachment to place extends beyond the ranch scale, to community or regional scale issues and decisions, such as rural wellbeing or biodiversity conservation, is a poorly understood but important area for future research.

\section{Conclusion}

This study aimed to answer the question: how does decision making operate on beef cattle ranches dealing with dynamic, uncertain and complex conditions? Our qualitative case study found that when social and biophysical conditions are relatively similar to previous experiences rancher decision-making is based upon long-standing traditions and culture, past lessons and historical decisions (path-dependence). Under higher levels of complexity 
or uncertainty, ranchers' decision-making processes are more relational and care-based, and include recognizing the need for care, taking responsibility, care-giving, and receiving care.

These findings related to ranchers' decision-making frameworks have implications for future outreach and collaborative research projects. For those practitioners who seek to improve rancher adaptive capacity and adoption of heterogeneity-promoting conservation practices, we recommend efforts to recognize that rancher decision making under uncertainty is not simply constrained by data or information availability, but also an ethical process. We also recommend efforts to build rancher capacities for care, and their flexibility, self-efficacy, and skills for problem solving in complex and dynamic situations. As noted by Cunfer et al. (2018) and Bennett (1969), ranch adaptations contribute to ranch community priorities and identities, but are often diverse and specific to conditions at ranch and community scales, and can be shaped by the influence of policy and social structures in addition to individuals, family groups, and cultural experiences. Outreach programs must consider how operational adaptations reflect ethical decision making, as well as more well-examined innovation adoption behavior, and how this interacts with uncertainty and complexity. In practice, this might involve place-based, long-term commitments from outreach professionals to engage whole families and communities in knowledge exchange and creation and planning with researchers regarding management for uncertain and extreme events. The co-creation of boundary objects such as community-derived maps, ranching decision-calendars and storytelling may also help bridge the ethical, ecological and economic aspects of adaptive ranch decision-making.

Our results suggest a need to recognize the role of emotions and moral concerns in adaptive management, support individual adaptive capacity in decision-making (this being a common but criticized recommendation in resilience-based approaches) (Joseph 2013), and that an opportunity exists to reassess the value of rancher care work in the broader context of rangeland social-ecological systems and biodiversity conservation. Engaging with a care-based process of decision making does not necessarily mean ranchers will make decisions that lead to the greatest possible conservation or production benefits. Ranchers are part of a complex colonial history of agricultural intensification in the Western US (Sayre 2004; Cunfer and Krausmann 2015). Their current paradigm of "managing for the middle" may result in additional reduction of vegetation structure heterogeneity at the pasture and/or ranch scale. And our results illustrate how a group of predominantly older, white ranchers, a majority of which were men, engaged in care work through an interdependence with wildlife, vegetation, livestock, and climate, across rural rangeland landscapes and communities. These ranchers navigated this complexity by a moral consideration of care giving and responsibility in moments of uncertainty.

Sayre et al. (2017, p. 348) described rangelands as "lands that have not (yet) been converted to other uses with higher rates of economic production and return, and their extant ecological diversity persists precisely because they have not been altered by more intensive land uses, which typically result in simplification," but we documented intentions and practices of ecological care that have not (yet) been reshaped to intensive productivist framings among ranchers operating where "anthromes meet their limits" (Sayre et al. 2017) in the Western Great Plains. Valuing this care work in dynamic, shifting social contexts under variable market and weather/ climate conditions on semi-arid rangeland systems may greatly enhance grassland biodiversity conservation efforts at a time when even small patches of habitat play a critical role conserving biodiversity (Wintle et al. 2019). Increasing the value assigned to the caregivers and acts of care that shape ranching decision-making can help position ranchers in the future as critical partners in biodiversity conservation and social-ecological adaptations to economic, cultural and ecological changes in a dynamic American West.

Acknowledgements The authors appreciate Dr. Emily Kachergis who helped initiate the research, developed the study design and collected data in Wyoming in 2012, and Dr. Kachergis, Dr. Paul Meiman, Brad Palmer, Dr. David Briske, Dr. Tracy Hruska, Julie Kennedy, Sam Cannon and Dr. David Augustine for helpful comments on the study and/ or manuscript. Research assistance provided by Pam Freeman, Nicole Kaplan and Shakota Dilley. Funding provided by: USDA-ARS; USDANIFA AFRI awards 2009-04442 and 2012- 38415-20328, Colorado Agricultural Experiment Station project COLO0698; Western Sustainable Agriculture, Research, and Education program (Project Number SW10-073); and the Center for Collaborative Conservation Fellows Program at Colorado State University.

\section{References}

Agrawal, A. 2008. The Role of Local Institutions in Adaptation to Climate Change. Paper prepared for the Social Dimensions of Climate Change, Social Development Department, The World Bank, Washington DC, March 5-6, 2008. http://documents.world bank.org/curated/en/234591468331456170/pdf/691280WP0P 11290utions0in0adaptation.pdf.

Aldrich, D.P., and M.A. Meyer. 2015. Social capital and community resilience. American Behavioral Scientist 59 (2): 254-269.

Augustine, D.J., D.T. Booth, S.E. Cox, and J.D. Derner. 2012. Grazing intensity and spatial heterogeneity in bare soil in a grazingresistant grassland. Rangeland Ecology and Management 65 (1): $39-46$.

Augustine, D.J., and J.D. Derner. 2012. Disturbance regimes and mountain plover habitat in shortgrass steppe: Large herbivore grazing does not substitute for prairie dog grazing or fire. The Journal of Wildlife Management 76 (4): 721-728.

Augustine, D.J., J.D. Derner, and D.G. Milchunas. 2010. Prescribed fire, grazing, and herbaceous plant production in shortgrass steppe. Rangeland Ecolology and Management 63 (3): 317-323. 
Augustine, D.J., S.J. Dinsmore, M.B. Wunder, V.J. Dreitz, and F.L. Knopf. 2008. Response of mountain plovers to plague-driven dynamics of black-tailed prairie dog colonies. Landscape Ecology 23 (6): 689-697.

Battiste, M., and J. Youngblood Henderson. 2000. Protecting indigenous knowledge and heritage: A global challenge. Saskatoon, SA, Canada: Purich Publishing Ltd.

Bement, R.E. 1969. A stocking-rate guide for beef production on bluegrama range. Journal of Range Management 22 (2): 83-86.

Bennett, J.W. 1969. Northern plainsmen: Adaptive strategy and agrarian life. Chicago, IL: Aldine.

Linda, Black Elk. 2016. Native science: Understanding and respecting other ways of thinking. Rangelands 38 (1): 3-4.

Bracy Knight, K., T.P. Toombs, and J.D. Derner. 2011. Cross-fencing on private US rangelands: Financial costs and producer risks. Rangelands 33 (2): 41-45.

Briske, D.D., S.D. Fuhlendorf, and F.E. Smeins. 2003. Vegetation dynamics on rangelands: A critique of the current paradigms. Journal of Applied Ecology 40 (4): 601-614. https://doi.org/10. 1046/j.1365-2664.2003.00837.x.

Briske, D.D., N.F. Sayre, L. Huntsinger, M.E. Fernández-Giménez, B. Budd, and J.D. Derner. 2011. Origin, persistence, and resolution of the rotational grazing debate: Integrating human dimensions into rangeland research. Rangeland Ecology \& Management 64 (4): 325-334

Brunson, M.W., and E.A. Burritt. 2009. Behavioral factors in rotational grazing systems. Rangelands 31 (5): 20-25.

Brunson, M.W., and L. Huntsinger. 2008. Ranching as a conservation strategy: Can old ranchers save the new west? Rangeland Ecology \& Management 61 (2): 137-147.

Bentley Brymer, A.L., D.T. Taylor, J.D. Wulfhorst, L.A. Torell, and R. Neil. 2018. Economic and social impact assessment of ranching on public lands: A guide to concepts, methods, and applications. Journal of Rangeland Applications 4: 1-16.

Charmaz, K. 2006. Constructing grounded theory: A practical guide through qualitative analysis. Thousand Oaks, CA: Sage.

Charnley, S., T.E. Sheridan, and G.P. Nabhan. 2014. Stitching the west back together: Conservation of working landscapes. Chicago, IL: University of Chicago Press.

Hill Collins, P. 2002. Black feminist thought: Knowledge, consciousness, and the politics of empowerment. New York: Routledge.

Coppock, D.L. 2011. Ranching and multiyear droughts in Utah: Production impacts, risk perceptions, and changes in preparedness. Rangeland Ecology \& Management 64 (6): 607-618.

Cunfer, G., and F. Krausmann. 2015. Adaptation on an agricultural frontier: Socio-ecological profiles of Great Plains settlement, 1870-1940. Journal of Interdisciplinary History 46 (3): 355-392.

Cunfer, G., A. Watson, and J. MacFadyen. 2018. Energy profiles of an agricultural frontier: The American Great Plains, 1860-2000. Regional Environmental Change 18 (4): 1021-1032.

Curtin, D. 1991. Toward an ecological ethic of care. Hypatia 6 (1): 60-74.

Davis, K.P., D.J. Augustine, A.P. Monroe, J.D. Derner, and C.L. Aldridge. 2019. Adaptive rangeland management benefits grassland birds utilizing opposing vegetation structure in the shortgrass steppe. Ecological Applications. https://doi.org/10.1002/ eap. 2020.

Deloria Jr., V. 1988. Custer died for your sins: An Indian manifesto. Norman: University of Oklahoma Press.

Derner, J.D., D.D. Briske, M. Reeves, T. Brown-Brandl, M. Meehan, D. Blumenthal, W. Travis, D.J. Augustine, H. Wilmer, J.D. Scasta, J. Henderickson, J. Volesky, L. Edwards, and D.E. Peck. 2018. Vulnerability of grazing and confined livestock in the northern
Great Plains to projected mid-and late-twenty-first century climate. Climatic Change 146 (1-2): 19-32.

Derner, J.D., J.K. Detling, and M.F. Antolin. 2006. Are livestock weight gains affected by black-tailed prairie dogs? Frontiers in Ecology and the Environment 4 (9): 459-464.

Derner, J.D., and D.J. Augustine. 2016. Adaptive management for drought on rangelands. Rangelands 38 (4): 211-215.

Derner, J.D., R.H. Hart, M.A. Smith, and J.W. Waggoner. 2008. Longterm cattle gain responses to stocking rate and grazing systems in northern mixed-grass prairie. Livestock Science 117 (1): 60-69.

Derner, J.D., W.K. Lauenroth, P. Stapp, and D.J. Augustine. 2009. Livestock as ecosystem engineers for grassland bird habitat in the western Great Plains of North America. Rangeland Ecology \& Management 62 (2): 111-118.

Didier, E.A., and M.W. Brunson. 2004. Adoption of range management innovations by Utah ranchers. Journal of Range Management 57 (4): 330-336.

Dominelli, L. 2013. Mind the gap: Built infrastructures, sustainable caring relations, and resilient communities in extreme weather events. Australian Social Work 66 (2): 204-217.

Dunn, B.H., A.J. Smart, R.N. Gates, P.S. Johnson, M.K. Beutler, M.A. Diersen, and L.L. Janssen. 2010. Long-term production and profitability from grazing cattle in the northern mixed grass prairie. Rangeland Ecology and Management 63 (2): 233-242.

Easdale, M.H., and S.E. Domptail. 2014. Fate can be changed! Arid rangelands in a globalizing world-A complementary co-evolutionary perspective on the current 'desert syndrome'. Journal of Arid Environments 100: 52-62.

Ellis, C. 2013. The symbiotic ideology: Stewardship, husbandry, and dominion in beef production. Rural Sociology 78 (4): 429-449.

Fernández-Giménez, M.E., B. Batkhishig, B. Batbuyan, and T. Ulambayar. 2015. Lessons from the dzud: Community-based rangeland management increases the adaptive capacity of Mongolian herders to winter disasters. World Development 68: 48-65. https ://doi.org/10.1016/j.worlddev.2014.11.015.

Fernández-Giménez, M.E., L.B. Jennings, and H. Wilmer. 2018. Poetic inquiry as a research and engagement method in natural resource science. Society and Natural Resources. https://doi. org/10.1080/08941920.2018.1486493.

Flanagan, O., and K. Jackson. 1987. Justice, care, and gender: The "Kohlberg-Gilligan" debate revisited. Ethics 97 (3): 622-637.

Ford, M.R., and C.R. Lowery. 1986. Gender differences in moral reasoning: A comparison of the use of justice and care orientations. Journal of Personality and Social Psychology 50 (4): 777-783.

Fuhlendorf, S.D., and D.M. Engle. 2001. Restoring heterogeneity on rangelands: ecosystem management based on evolutionary grazing patterns: We propose a paradigm that enhances heterogeneity instead of homogeneity to promote biological diversity and wildlife habitat on rangelands grazed by livestock. BioScience 51 (8): 625-632.

Fuhlendorf, S.D., D.M. Engle, R.D. Elmore, R.F. Limb, and T.G. Bidwell. 2012. Conservation of pattern and process: Developing an alternative paradigm of rangeland management. Rangeland Ecology \& Management 65 (6): 579-589.

Fuhlendorf, S.D., W.C. Harrell, D.M. Engle, R.G. Hamilton, C.A. Davis, and D.M. Leslie Jr. 2006. Should heterogeneity be the basis for conservation? Grassland bird response to fire and grazing. Ecological Applications 16 (5): 1706-1716.

Fulton, A., F. Vanclay, D. Pannel, and F. Vanclay. 2011. Enabling change in family farm businesses. Changing land management, 95-106. Collingwood, VIC, Australia: CSIRO.

Galvin, K.A., R.S. Reid, M.E. Fernández-Giménez, D. ole Kaelo, B. Baival, and M. Krebs. 2016. Co-design of transformative research for rangeland sustainability. Current Opinion in 
Environmental Sustainability 20: 8-14. https://doi.org/10.1016/j. cosust.2016.03.003.

Gibson, D.J. 2009. Grasses and grassland ecology. Oxford: Oxford University Press.

Gilligan, C. 1982. In a different voice. Cambridge: Harvard University Press.

Glaser, B.G., and A.L. Strauss. 2017. Discovery of grounded theory: Strategies for qualitative research. New York: Routledge.

Glesne, C. 1992. Becoming qualitative researchers: An introduction. White Plains, N.Y.: Longman.

Gosnell, H., and J. Abrams. 2011. Amenity migration: Diverse conceptualizations of drivers, socioeconomic dimensions, and emerging challenges. GeoJournal 76 (4): 303-322.

Hamilton, T.W., J.P. Ritten, C.T. Bastian, J.D. Derner, and J.A. Tanaka. 2016. Economic impacts of increasing seasonal precipitation variation on southeast Wyoming cow-calf enterprises. Rangeland Ecology \& Management 69 (6): 465-473.

Haraway, D.J. 1988. Situated knowledges: The science question in feminism and the privilege of partial perspective. Feminist studies 14 (3): 575-599.

Haraway, D.J. 2003. The companion species manifesto: Dogs, people, and significant otherness. Chicago: Prickly Paradigm Press.

Harding, S. 2006. Science and social inequality: Feminist and postcolonial issues. Chicago: University of Illinois Press.

Held, V. 1995. The meshing of care and justice. Hypatia 10 (2): 128-132.

Herman, A. 2015. Enchanting resilience: Relations of care and people-place connections in agriculture. Journal of Rural Studies 42: 102-111.

Holling, C.S., and L.H. Gunderson. 2002. Resilience and adaptive cycles. Panarchy: Understanding transformations in human and natural systems. Washington, DC: Island Press.

Holling, C.S., and G.K. Meffe. 1996. Command and control and the pathology of natural resource management. Conservation Biology 10 (2): 328-337.

Holloway, L. 2002. Smallholding, hobby-farming, and commercial farming: ethical identities and the production of farming spaces. Environment and Planning A 34 (11): 2055-2070.

Hovick, T.J., R.D. Elmore, and S.D. Fuhlendorf. 2014. Structural heterogeneity increases diversity of non-breeding grassland birds. Ecosphere 5 (5): 62. https://doi.org/10.1890/ES14-00062.1.

Hruska, T., D. Toledo, R. Sierra-Corona, and V. Solis-Gracia. 2017. Social-ecological dynamics of change and restoration attempts in the Chihuahuan Desert grasslands of Janos Biosphere Reserve. Mexico. Plant Ecology 218 (1): 67-80. https://doi.org/10.1007/ s11258-016-0692-8.

Huang, R. 2016. R-based qualitative data analysis. http://rqda.r-forge .r-project.org/.

Huntsinger, L., L. Buttolph, and P. Hopkinson. 1997. Ownership and management changes on California hardwood rangelands: 1985 to 1992. Journal of Range Management 50 (4): 423.

Irisarri, J.G., J.D. Derner, J.P. Ritten, and D.E. Peck. 2019. Beef production and net revenue variability from grazing systems on semiarid grasslands of North America. Livestock Science 220: 93-99.

Jaggar, A.M. 2015. Just methods: An interdisciplinary feminist reader. Boulder, CO: Paradigm Publishers.

Johnson, J.T., and B. Murton. 2007. Re/placing native science: Indigenous voices in contemporary constructions of nature. Geographical Research 45 (2): 121-129.

Joseph, J. 2013. Resilience as embedded neoliberalism: A governmentality approach. Resilience 1 (1): 38-52.

Joshi, O., T.A. Becerra, D.M. Engle, S.D. Fuhlendorf, and R.D. Elmore. 2017. Factors affecting public preferences for grassland landscape heterogeneity in the Great Plains. Environmental Management 60 (5): 922-930.
Joyce, L.A., D.D. Briske, J.R. Brown, H.W. Polley, B.A. McCarl, and D.W. Bailey. 2013. Climate change and North American rangelands: Assessment of mitigation and adaptation strategies. Rangeland Ecology \& Management 66 (5): 512-528.

Kachergis, E., J.D. Derner, B.B. Cutts, L.M. Roche, V.T. Eviner, M.N. Lubell, and K.W. Tate. 2014. Increasing flexibility in rangeland management during drought. Ecosphere 5 (6): 1-14.

Knapp, C.N., and M.E. Fernández-Giménez. 2008. Knowing the land: A review of local knowledge revealed in ranch memoirs. Rangeland Ecology and Management. 61 (2): 148-155.

Knight, R.L. 2007. Ranchers as a keystone species in a West that works. Rangelands 29 (5): 4-9.

Knopf, F.L., and F.B. Samson. 1997. Conservation of grassland vertebrates. Ecology and conservation of Great Plains vertebrates. New York, NY: Springer.

Lai, P., and U.P. Kreuter. 2012. Examining the direct and indirect effects of environmental change and place attachment on land management decisions in the Hill Country of Texas, USA. Landscape and Urban Planning 104 (3-4): 320-328.

Lawson, V. 2007. Geographies of care and responsibility. Annals of the Association of American Geographers 97 (1): 1-11.

Lawson, V. 2009. Instead of radical geography, how about caring geography? Antipode 41 (1): 210-213.

Leopold, A. 1949. A sand county almanac and sketches here and there. Oxford, UK: Oxford University Press.

Lien, A.M., C. Svancara, W. Vanasco, G.B. Ruyle, and L. LópezHoffman. 2017. The land ethic of ranchers: A core value despite divergent views of government. Rangeland Ecology \& Management 70 (6): 787-793.

Lincoln, Y.S., and E.G. Guba. 1986. But is it rigorous? Trustworthiness and authenticity in naturalistic evaluation. New directions for program evaluation 1986 (30): 73-84.

Lubell, M.N., B.B. Cutts, L.M. Roche, M. Hamilton, J.D. Derner, E. Kachergis, and K.W. Tate. 2013. Conservation program participation and adaptive rangeland decision-making. Rangeland Ecology \& Management 66 (6): 609-620.

Lund, C. 2014. Truth comes out. On Conterfeit Blues. Nashville: New West.

MacDonald, J.M., and W.D. McBride. 2009. The transformation of US livestock agriculture scale, efficiency, and risks. Economic Information Bulletin. https://doi.org/10.2139/ssrn.1354028.

Marshall, N.A. 2010. Understanding social resilience to climate variability in primary enterprises and industries. Global Environmental Change 20 (1): 36-43. https://doi.org/10.1016/j.gloen vcha.2009.10.003.

Marshall, N.A. 2016. Adaptive capacity on the northern Australian rangelands. Rangeland Journal 37 (6): 617-622.

Marshall, N.A., and A. Smajgl. 2013. Understanding variability in adaptive capacity on rangelands. Rangeland Ecology \& Management 66 (1): 88-94.

Marshall, N.A., and C.J. Stokes. 2014. Influencing adaptation processes on the Australian rangelands for social and ecological resilience. Ecology and Society 19 (2): 14.

Milchunas, D.G., and W.K. Lauenroth. 1993. Quantitative effects of grazing on vegetation and soils over a global range of environments. Ecological Monographs 63 (4): 327-366. https://doi. org/10.2307/2937150.

Milchunas, D.G., O.E. Sala, and W.K. Lauenroth. 1988. A generalized model of the effects of grazing by large herbivores on grassland community structure. The American Naturalist 132 (1): 87-106.

Morse, J.M., M. Barrett, M. Mayan, K. Olson, and J. Spiers. 2008. Verification strategies for establishing reliability and validity in qualitative research. International journal of qualitative methods 1 (2): 13-22. 
Noddings, N. 1984. Caring: A feminine approach to ethics and moral education. Berkeley: University of California Press.

Noy, C. 2008. Sampling knowledge: The hermeneutics of snowball sampling in qualitative research. International Journal of Social Research Methodology 11 (4): 327-344.

Oeberst, A., J. Kimmerle, and U. Cress. 2016. What is knowledge? Who creates it? Who possesses it? The need for novel answers to old questions. Mass collaboration and education. New York, NY: Springer.

Otkin, J.A., M.C. Anderson, C. Hain, M. Svoboda, D. Johnson, R. Mueller, T. Tadesse, B. Wardlow, and J. Brown. 2016. Assessing the evolution of soil moisture and vegetation conditions during the 2012 United States flash drought. Agricultural and Forest Meteorology 218: 230-242.

Plumwood, V. 1991. Nature, self, and gender: Feminism, environmental philosophy, and the critique of rationalism. Hypatia 6 (1): 3-27.

Porensky, L.M., J.D. Derner, D.J. Augustine, and D.G. Milchunas. 2017. Plant community composition after $75 \mathrm{yr}$ of sustained grazing intensity treatments in shortgrass steppe. Rangeland Ecology \& Management 70 (4): 456-464. https://doi. org/10.1016/j.rama.2016.12.001.

Prokopy, L.S., K. Floress, J.G. Arbuckle, S.P. Church, F.R. Eanes, Y. Gao, B.M. Gramig, P. Ranjan, and A.S. Singh. 2019. Adoption of agricultural conservation practices in the United States: Evidence from 35 years of quantitative literature. Journal of Soil and Water Conservation 74 (5): 520-534.

Ragin, C.C. 2014. The Comparative Method: Moving Beyond Qualitative and Quantitative Strategies. Oakland: University of California Press.

Reeves, J.L., J.D. Derner, M.A. Sanderson, M.K. Petersen, L.T. Vermeire, J.R. Hendrickson, and S.L. Kronberg. 2013. Temperature and precipitation affect steer weight gains differentially by stocking rate in northern mixed-grass prairie. Rangeland Ecology and Management 66 (4): 438-444.

Ritten, J.P., W.M. Frasier, C.T. Bastian, and S.T. Gray. 2010. Optimal rangeland stocking decisions under stochastic and climateimpacted weather. American Journal of Agricultural Economics 92 (4): 1242-1255.

Rizza, C., and A. Guimarães Pereira. 2014. Building a resilient community through social network: Ethical considerations about the 2011 Genoa floods. In Proceedings of the 11th International ISCRAM Conference-University Park, Pennsylvania, USA, eds. S.R. Hilz, M.S. Pfaff, L. Plotnick, and P.C. Shih.

Roche, L.M., B.B. Cutts, J.D. Derner, M.N. Lubell, and K.W. Tate. 2015. On-ranch grazing strategies: Context for the rotational grazing dilemma. Rangeland Ecology \& Management 68 (3): 248-256.

Roche, L.M. 2016. Adaptive rangeland decision-making and coping with drought. Sustainability 8 (12): 1334.

Roesch-McNally, G., J.G. Arbuckle, and J.C. Tyndall. 2018. Soil as social-ecological feedback: Examining the "ethic" of soil stewardship among corn belt farmers. Rural Sociology 83 (1): 145-173.

Ruff, S.P., D. Ee Peck, C.T. Bastian, and W.E. Cook. 2016. Economics of transitioning from a cow-calf-yearling operation to a stocker operation. Journal of ASFMRA 55-76.

Ruppert, J.C., K. Harmoney, Z. Henkin, H.A. Snyman, M. Sternberg, W. Willms, and A. Linstädter. 2015. Quantifying drylands' drought resistance and recovery: The importance of drought intensity, dominant life history and grazing regime. Global Change Biology 21 (3): 1258-1270.

Sayre, N.F., and M.E. Fernández-Giménez. 2003. The genesis of range science, with implications for current development policies. Proceedings of the 7th International Rangelands Congress, Durban,
South Africa, N. Allsopp, A.R. Palmer, S.J. Milton, K.P. Kirman, G.I.H. Kerley, C.R. Hurt, C.J. Brown, eds.

Sayre, N.F. 2004. Viewpoint: The need for qualitative research to understand ranch management. Rangeland Ecology and Management 57 (6): 668-674.

Sayre, N.F. 2017. The politics of scale: A history of rangeland science. Chicago: The University of Chicago Press.

Sayre, N.F., D.K. Davis, B. Bestelmeyer, and J.C. Williamson. 2017. Rangelands: Where anthromes meet their limits. Land 6 (2): 31.

Shisler, R.C., and J. Sbicca. 2019. Agriculture as carework: The contradictions of performing femininity in a male-dominated occupation. Society and Natural Resources 32 (8): 875-892.

Sierra-Corona, R., A. Davidson, E.L. Fredrickson, H. Luna-Soria, H. Suzan-Azpiri, E. Ponce-Guevara, and G. Ceballos. 2015. Blacktailed prairie dogs, cattle, and the conservation of North America's arid grasslands. PLOS ONE 10 (3): e0118602.

Skagen, S.K., D.J. Augustine, and J.D. Derner. 2018. Semi-arid grassland bird responses to patch-burn grazing and drought. The Journal of Wildlife Management 82 (2): 445-456. https://doi. org/10.1002/jwmg.21379.

Sorice, M.G., J.R. Conner, U.P. Kreuter, and R.N. Wilkins. 2012. Centrality of the ranching lifestyle and attitudes toward a voluntary incentive program to protect endangered species. Rangeland Ecology \& Management 65 (2): 144-152.

Sorice, M.G., U.P. Kreuter, B.P. Wilcox, and W.E. Fox. 2014. Changing landowners, changing ecosystem? Land-ownership motivations as drivers of land management practices. Journal of Environmental Management 133: 144-152.

Specht, J. 2019. Red meat republic: A hoof-to-table history of how beef changed America. Princeton, NJ: Princeton University Press.

Sun, D., P. Hyland, and O. Bosch. 2014. A systemic view of innovation adoption in the Australian beef industry. Systems Research and Behavioral Science 32: 646-657. https://doi.org/10.1002/ sres.2251.

TallBear, K. 2017. Beyond the life/not life binary: A feminist-indigenous reading of cryopreservation, interspecies thinking and the new materialisms. In Cryopolitics: Frozen life in a melting world, ed. J. Randin and E. Kowal, 179-202. Cambridge: MIT Press.

Tews, J., U. Brose, V. Grimm, K. Tielbörger, M.C. Wichmann, M. Schwager, and F. Jeltsch. 2004. Animal species diversity driven by habitat heterogeneity/diversity: The importance of keystone structures. Journal of Biogeography 31 (1): 79-92.

Toombs, T.P., and M.G. Roberts. 2009. Are natural resources conservation service range management investments working at crosspurposes with wildlife habitat goals on western United States rangelands? Rangeland Ecology \& Management 62 (4): 351-355.

Torell, L.A. 2010. Economics of flexible versus conservative stocking strategies to manage climate variability risk. Rangeland Ecology and Management 63 (4): 415-425.

Torell, L.A., N.R. Rimbey, J.A. Tanaka, and S.A. Bailey. 2001. The lack of a profit motive for ranching: implications for policy analysis. Current Issues in Rangeland Resource Economics: Symposium Proceedings (2001) 16629, Western Regional Coordinating Committee on Rangeland Economics: WCC-55. https://doi. org/10.22004/ag.econ.16629.

Tronto, J.C. 1994. Moral boundaries: A political argument for an ethic of care. New York, NY: Routledge.

Tronto, J.C. 1999. Care ethics: Moving forward. Hypatia 14 (1): 112-119.

Tuhiwai Smith, L. 2013. Decolonizing methodologies: Research and Indigenous peoples. London: Zed Books.

Turner, B.L., M. Wuellner, T. Nichols, and R. Gates. 2014. Dueling land ethics: Uncovering agricultural stakeholder mental models to better understand recent land use conversion. Journal of Agricultural and Environmental Ethics 27 (5): 831-856. 
Twidwell, D., B.W. Allred, and S.D. Fuhlendorf. 2013. National-scale assessment of ecological content in the world's largest land management framework. Ecosphere 4 (8): 1-27.

USDA NASS. 31 May 2019. Prices received for cattle by month, United States. www.nass.usda.gov/Charts_and_Maps/Agricultur al_Prices/priceca.php.

Warren, K.J. 1987. Feminism and ecology: Making connections. Environmental ethics 9 (1): 3-20.

White, C., and C. Conley. 2007. Grassbank 2.0. Rangelands 29 (3): 27-31.

Whyte, K.P., and C.J. Cuomo. 2016. Ethics of caring in environmental ethics. The Oxford handbook of environmental ethics, 234. Oxford: Oxford University Press.

Wilmer, H., D.J. Augustine, J.D. Derner, M.E. Fernández-Giménez, D.D. Briske, L.M. Roche, K.W. Tate, and K.E. Miller. 2018. Diverse management strategies produce similar ecological outcomes on ranches in western Great Plains: Social-ecological assessment. Rangeland Ecology and Management 71 (5): 626636. https://doi.org/10.1016/j.rama.2017.08.001.

Wilmer, H., and M.E. Fernández-Giménez. 2016. Voices of Change: Narratives from ranching women of the southwestern United States. Rangeland Ecology and Management 69 (2): 150-158. https://doi.org/10.1016/j.rama.2015.10.010.

Wilmer, H., and M.E. Fernández-Giménez. 2015. Rethinking rancher decision-making: A grounded theory of ranching approaches to drought and succession management. The Rangeland Journal 37 (5): 517-528.

Wintle, B.A., H., Kujala, A. Whitehead, A. Cameron, S. Veloz, A. Kukkala, A. Moilanen, A. Gordon, P.E. Lentini, P.E., N.C. Cadenhead and S.A. Bekessy. 2019. Global synthesis of conservation studies reveals the importance of small habitat patches for biodiversity. Proceedings of the National Academy of Sciences 116 (3): 909-914.

Wylie, J. 2017. Vanishing points: An essay on landscape, memory and belonging. Irish Geography 50 (1): 3-18.

York, E.C., M.W. Brunson, and K.B. Hulvey. 2019. Influence of ecosystem services on management decisions by public land ranchers in the intermountain west, United States. Rangeland Ecology \& Management 72 (4): 721-728.

Publisher's Note Springer Nature remains neutral with regard to jurisdictional claims in published maps and institutional affiliations.
Hailey Wilmer is the USDA Northern Plains Climate Hub Fellow. She is a rangeland ecologist and social scientist working in Great Plains ranching systems with the USDA-ARS Rangeland Resources and Systems Research Unit. Her work focuses on methods to connect ranchers, managers, conservation groups and researchers with one another and with working landscapes through participatory grazing research and engagement.

Maria E. Fernandez-Gimenez is a rangeland and human ecologist with expertise in rangeland assessment, monitoring, collaborative and community-based natural resource management. She is Associate Director for Research at the Center for Collaborative Conservation and Professor in the Department of Forest and Rangeland Stewardship at Colorado State University.

Shayan Ghajar is a PhD Candidate in the School of Plant and Environmental Sciences at Virginia Tech where he studies grassland ecosystems and forages.

Peter Leigh Taylor is Professor and Chair of the Department of Sociology at Colorado State University. He specializes in natural resource and environmental sociology and has published extensively on organizational problems of community-based forest management in Mexico, Guatemala and Bolivia. His current research focuses on environmental flow cooperation on the Colorado River in Colorado and on agricultural water issues in the Colorado River Basin.

Caridad Souza is Special Assistant Professor and Director of the Center for Women Studies and Gender Research at Colorado State University. Her teaching and research interests include contemporary race $\&$ ethnic relations and theories, poverty, multiracial and decolonial feminisms, and critical ethnography. Caridad has written about teenage pregnancy, work, gender and households, Latina sexualities, and feminist pedagogies.

Justin D. Derner is a rangeland scientist and serves as Research Leader for the USDA-ARS Rangeland Resources \& Systems Research Unit. The Unit's research project entitled "Adaptive Grazing Management and Decision Support to Enhance Ecosystem Services in the Western Great Plains" has a multi-disciplinary team of scientists developing and delivering tools for semi-arid rangeland management for multiple ecosystem goods and services with changing climatic conditions. 